\title{
The performance of polymer beads in water-based mud and its application in high-temperature well
}

\author{
Nur Suriani Mamat • Issham Ismail • \\ Shahrir Hashim • Azmi Kamis • \\ Aizal Haziq Abdul Razak
}

Received: 14 March 2012/ Accepted: 5 May 2013/Published online: 25 May 2013

(c) The Author(s) 2013. This article is published with open access at Springerlink.com

\begin{abstract}
The major concern in multilateral drilling is the torque and drag that arises as we drill deeper coupled with the escalation of bottomhole temperature, which can be overcome through the use of a lubricant: a solid or liquid form. Solid lubricants have been proved to be able to reduce the coefficient of friction substantially. In this research work, polymer beads were used as a lubricating agent in a high-temperature condition. The polymer beads which possessed improved physical properties were constructed using polymerization of styrene monomer added with divinylbenzene. The molecular structure and thermal properties of the polymer beads were evaluated using Fourier transform infrared analysis (FTIR) and thermogravimetric analysis (TGA), respectively. The lubricity test was conducted on four different types of sample, namely
\end{abstract}

N. S. Mamat $(\bowtie) \cdot$ I. Ismail · A. Kamis

Department of Petroleum Engineering, Faculty of Petroleum and Renewable Energy Engineering, Universiti Teknologi Malaysia, UTM Johor Bahru, Johor 81310, Malaysia

e-mail: suriani@petroleum.utm.my

I. Ismail

e-mail: issham@petroleum.utm.my

A. Kamis

e-mail: azmik@petroleum.utm.my

S. Hashim

Department of Polymer Engineering, Faculty of Chemical Engineering, Universiti Teknologi Malaysia, UTM Johor Bahru, 81310 Johor, Malaysia

e-mail: shahrir@cheme.utm.my

A. H. Abdul Razak

5 Murphy Oil Co. Ltd, Level 31, Tower 2, Petronas Twin

Towers, Kuala Lumpur City Center, 50088 Kuala Lumpur, Malaysia

e-mail: aizalhaziq@gmail.com oil-based mud, water-based mud, and water-based mud with polymer and glass beads, at temperatures ranging from 60 to $180{ }^{\circ} \mathrm{C}$. The experimental results were found to give an average reduction of $27.5 \%$ of coefficient of friction at elevated temperature and the rheological properties experienced slight changes above $100{ }^{\circ} \mathrm{C}$ as compared to water-based mud. In a nutshell, the polymer beads show the potential to be used as a lubricating agent in hightemperature conditions.

Keywords Coefficient of friction - High-temperature wells Polymer beads $\cdot$ Solid lubricant $\cdot$ Water-based mud . Lubricity

\section{Introduction}

Directional drilling and horizontal drilling techniques have led to the invention of extended reach drilling (ERD) (K \& M Technology 2003). Nowadays, it becomes a common practice throughout the world as a means to reach a maximum number of wells from single location. This technique also has the ability to achieve horizontal well departures and total vertical depth to deviation ratio beyond the conventional experience of a particular field. The particular concerns on this technique are the torque and drag arises as we drill farther and deeper. Torque and drag minimization become a big challenge for ERD (Payne et al. 1995; Rubiandini 2008).

Mud lubricity is an indicator to measure the effect of torque and drag in ERD. The usage of oil-based mud as a drilling fluid had already proved to increase mud lubricity. However, due to the environmental concern that caused by the consumption of oil-based mud, it is strictly prohibited. So, the most suitable drilling fluid for ERD is water-based mud. Even though the performance of this type of drilling 
fluid is not as encouraging as oil-based mud in reducing torque and drag, an addition of the additive would mitigate the torque and drag problem (Aston et al. 1998). Usage of synthetic- or mineral-oil-based mud may give better lubricity performance than water-based mud, but it is proved more costly.

Solid particle is one of the lubricating agents, which is being used widely in water-based mud. This type of lubricating agent has the advantage of being compatible to all mud chemistry compared to the liquid type. Liquid lubricant is depending greatly on mud type to work effectively and it may be reduced by the presence of another mud additives (Cameroon 2001). It works by creating a thin film between two surfaces to minimize any contact between the surfaces. Meanwhile, solid particles usually beads will create a small stand-off distance for pressure communication and flow as well (Schamp and Estes 2006).

The result from the previous study had shown that the microbeads could reduce the friction in water-based mud significantly. Therefore, this research study was conducted to evaluate the characteristic and the performance of polymer beads in water-based mud as a lubricating agent under a high-temperature well condition.

\section{Materials and experimental procedures}

Four different drilling muds were used in this study: waterbased mud, oil-based mud, water-based mud with polymer, and water-based mud with glass beads. Polymer beads were constructed using polymerization of styrene monomer and divinylbenzene. The constructed polymer beads have undergone several tests to determine its properties. Basically, all of the mud samples underwent lubricity and rheological test under normal and elevated temperatures.

The preparation of water-based mud

In the experimental works, fresh water-based mud was used as the base mud. It was prepared using water, potassium chloride $(\mathrm{KCl})$, caustic soda $(\mathrm{NaOH})$, bentonite, hydro-PAC, hydro-STAR and polymer beads. The mud additives were supplied by Scomi Oiltools. The compositions of drilling mud used were based on 1 lab barrel (1 lab barrel $=350 \mathrm{cc}$ ).

The preparation of oil-based mud

In order to make a comparison for reduction of coefficient of friction, oil-based mud had been used. This is important since we need to design our mud that can replicate the oilbased mud's lubricity which possesses low value of coefficient of friction. The mud additives were supplied by Scomi Oiltools and the mud compositions were prepared based on 1 lab barrel (1 lab barrel $=350 \mathrm{cc}$ ).

The preparation of polymer beads

For this study, the polymer beads were constructed via the emulsion polymerization process. It was then added into water-based mud to study its effectiveness as a lubricating agent. The step of the polymer beads construction can be divided into two parts: purification styrene and divinylbenzene and emulsion. As shown in Figs. 1 and 2, the experimental apparatus and arrangement for polymer beads polymerization process.

Polymer beads characterization

The study on polymer beads properties was done to determine its ability to work under harsh wellbore condition. It also determines its compatibility to work in a drilling mud as a lubricating agent. The tests conducted on polymer beads sample are as follows:

1. Themogravimetric analysis (TGA)

2. Fourier Transform Infrared (FTIR) analysis

\section{Lubricity test}

Four different types of drilling mud sample were used in this study. The temperature range was from 60 to $180{ }^{\circ} \mathrm{C}$. Lubricity Evaluation Monitor (LEM 4100) (Temco 2006) was used to study the mud lubricity behavior at normal and elevated temperatures. Note that all experiments were conducted in the following specific conditions:

Test chamber pressure $=300-600 \mathrm{psig}$.

Test chamber temperature $=60-180{ }^{\circ} \mathrm{C}$.

Reservoir temperature $=60-180^{\circ} \mathrm{C}$.

Type of surface contact $=$ Steel/rock.

\section{Rheological properties study}

The rheological properties of mud were studied at normal and elevated temperatures. For elevated temperature, the sample was placed in an aging cell and then heated-up in a roller oven for $16 \mathrm{~h}$. The rheological properties tested in this study are as follows:

1. Mud weight

2. Plastic viscosity

3. Yield point

4. Gel strength

5. Fluid loss 


\section{Mud cake thickness}

The experiments were conducted using standard laboratory equipment that recommended by American Petroleum Institute-Recommended Practices for Field Testing Waterbased Drilling Fluids (API-RP-13B-1) (American Petroleum Institute 2009). The study of rheological properties is of utmost importance to determine the mud performance in sustaining its performance at high temperatures.

\section{Results and discussion}

The discussion of experimental results comprises polymer beads characteristics, mud lubricity performance, and rheological property changes of all muds at normal and elevated temperatures.

Polymer beads characteristics

Study conducted on polymer beads showed that it was suitable to be used under high-temperature condition due to its thermal stability. Based on the test conducted, it was found of having $24 \%$-degree of cross-linking which was a

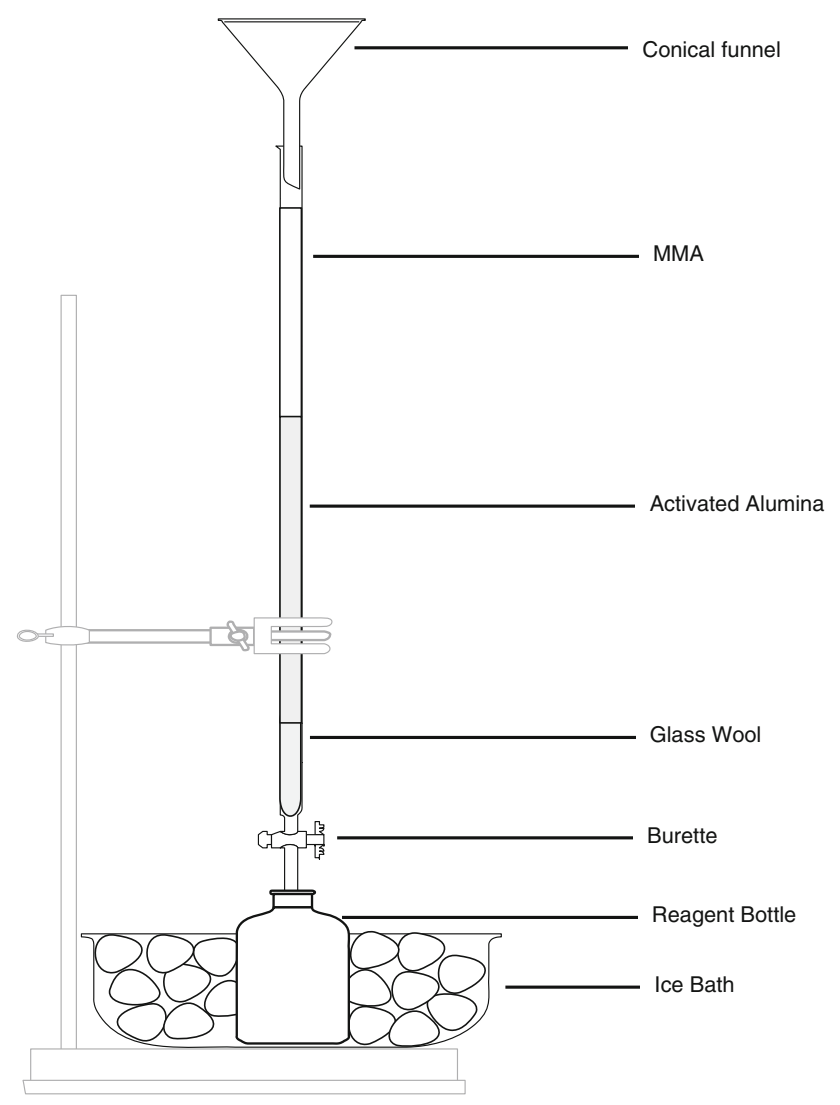

Fig. 1 Apparatus arrangement for inhibitor removal (Isnin and Bakar 2007; Nik Mat and Bakar 2007) good value to work in drilling muds. The polymer beads were found to be decomposed at $423{ }^{\circ} \mathrm{C}$, and the presence of benzene ring in the polymer beads allows the melting point to be that high, as shown in Figs. 3 and 4. This finding shows that the synthesized polymer beads would be able to sustain the Malaysian wellbore condition with average temperature $104{ }^{\circ} \mathrm{C}$ (Selamat et al. 2008) and can be up to $160{ }^{\circ} \mathrm{C}$ as recorded by Angsi Field (Murrey et al. 2003). Size of polymer beads which gave the lowest coefficient of friction in previous study was found to be in the range of $66-88 \mu \mathrm{m}$.

\section{Mud lubricity}

The main focus of this research study was to evaluate the lubricity among water-based mud, oil-based mud, waterbased mud with glass beads, and water-based mud with polymer beads in high-temperature conditions. The temperature used for this study was from 60 to $180{ }^{\circ} \mathrm{C}$. The equipment used for this study was Lubricity Evaluation Monitor (LEM-4100). The pump rate and bob speed were kept constant at 850 and $250 \mathrm{rpm}$, respectively. Pump speed represents the rate of mud flow into wellbore through nozzle on a drill bit while bob rotation represents drill bit rotation in a wellbore. Stationary sample used for this study was steel to rock surface.

Figure 5 shows the average coefficient of friction $(\mathrm{CoF})$ for all of the samples tested at different temperatures. It showed that the polymer beads gave a comparable performance to glass beads in water-based mud at the elevated temperatures as a lubricity agent. This gives us an indication that the polymer beads have the potential to work well in a high-temperature condition. The average $\mathrm{CoF}$ reduction for polymer beads was $27.5 \%$ while for glass beads was $26.5 \%$. The oil-based mud recorded about $86.8 \% \mathrm{CoF}$ reduction.

Polymer employed for this study was made of polystyrene (PS) crosslinked with divinylbenzene (DVB). This copolymer is thermally stable with properties of pore size distribution and degree of crosslinking are easy to control as mentioned by Skalle et al. (1999). As shown in the Fig. 5, the mud plus polymer beads gave comparable performance with the mud plus glass beads and do not affect by the temperature changes. This findings was supported by polymer beads characterization analysis. Based on polymer beads characterization, it was found to decompose at $423{ }^{\circ} \mathrm{C}$. This indicates its ability of surviving under the high downhole temperature condition.

\section{Rheological properties}

Several tests were conducted to investigate the mud rheological properties in normal and elevated temperature conditions. The results were as follows: 
Fig. 2 Standard apparatus arrangements for grafting copolymerization (Isnin and Bakar 2007; Nik Mat and Bakar 2007)

Fig. 3 Thermogravimetric analysis on polymer beads

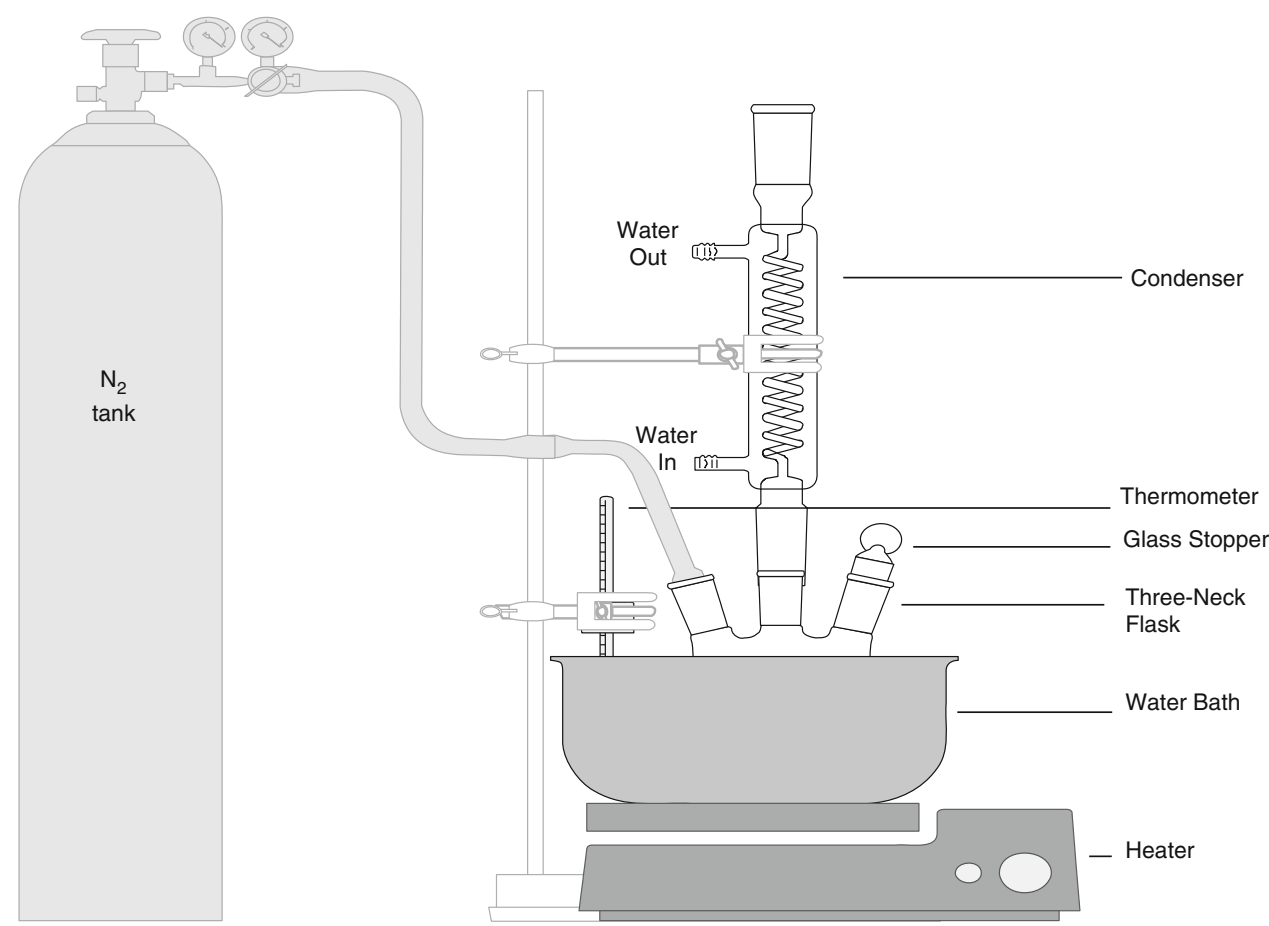

\section{Mud weight}

Figure 6 shows the changes experienced by those four muds after being subjected to different elevated temperatures. Water-based mud experienced significant changes after being exposed to elevated temperatures. For waterbased mud with polymer beads, it gave almost the same performance as water-based mud with glass beads. This is due to the melting points of these two products which were above $180{ }^{\circ} \mathrm{C}$. This was proved by the data from TGA analysis which recorded that the weight loss happened at
$423{ }^{\circ} \mathrm{C}$, which represents the melting point. Meanwhile for glass beads, the melting point is at $730{ }^{\circ} \mathrm{C}$. The presence of this glass and polymer beads in drilling mud did not have any effect on their mud weight.

\section{Plastic viscosity}

With the addition of a solid lubricant in drilling mud, the value of plastic viscosity will increase. Skalle at al. (1999) highlighted in their study that the presence of beads increases viscosity. Despite the slight fluctuation in value of plastic 


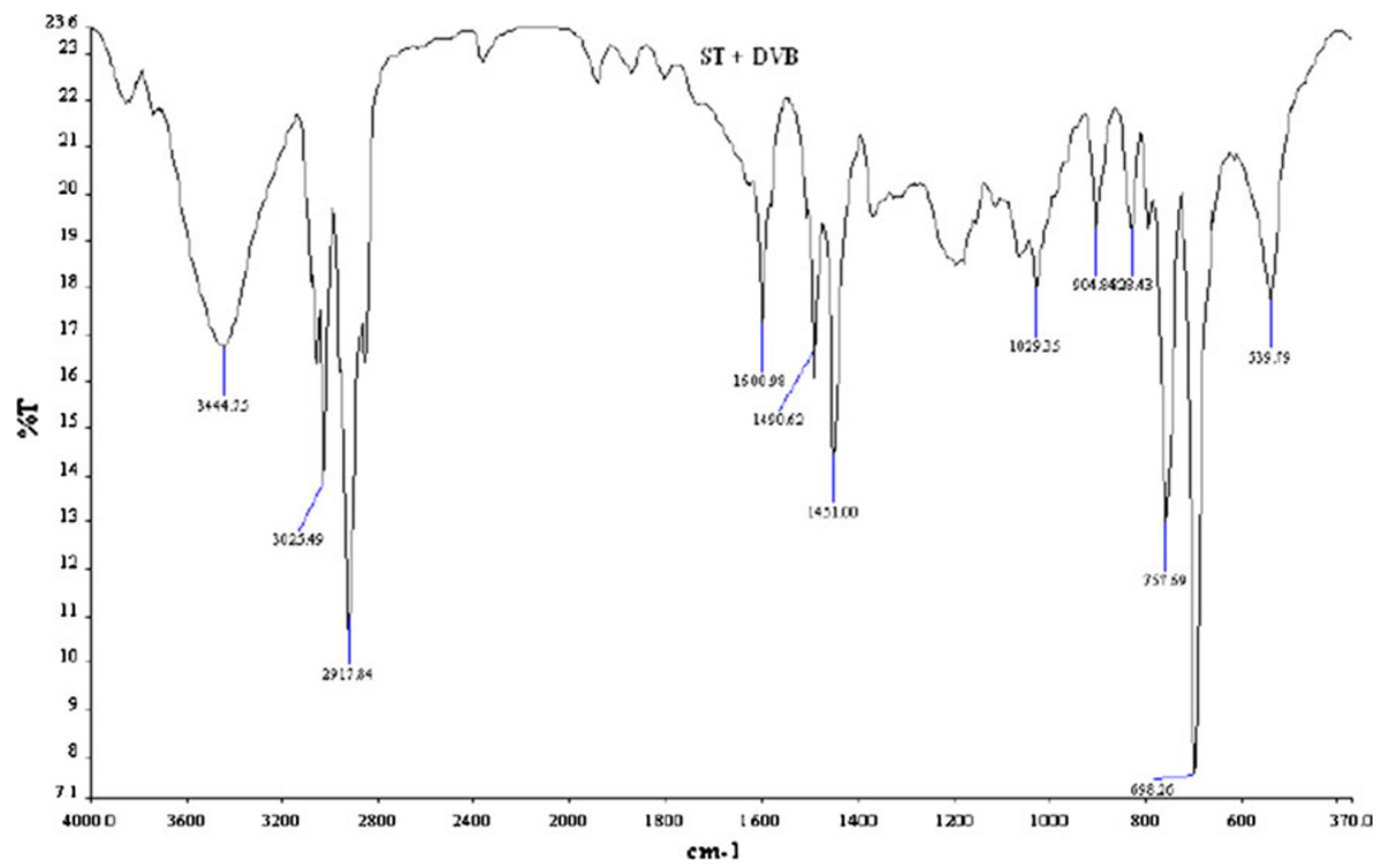

Fig. 4 FTIR analysis on polymer beads

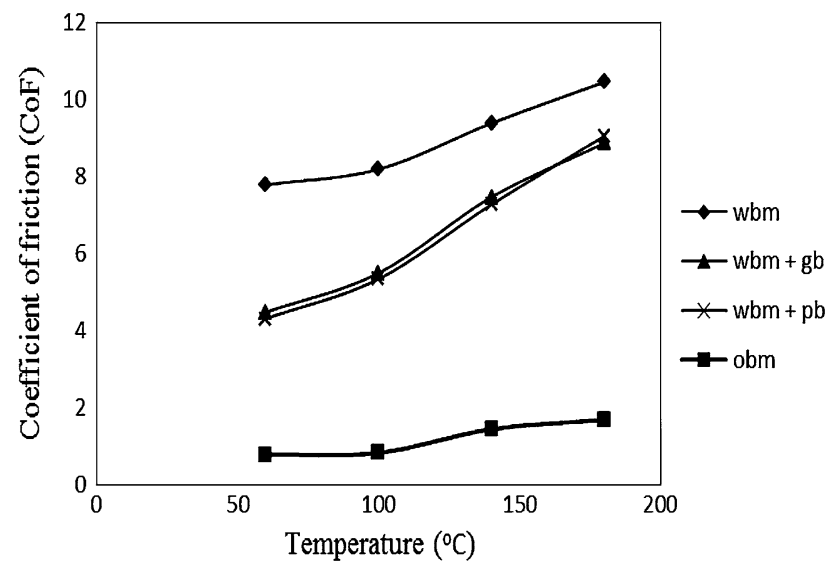

Fig. 5 Comparison of average $\mathrm{CoF}$ against the elevated temperature Rheological properties

viscosity, it still shows a good agreement with 'Scomi Oiltools' recommended $20 \mathrm{cp}$ of plastic viscosity value

Figure 7 shows the plastic viscosity of the tested mud at different elevated temperatures. Oil-based mud showed an increasing value of plastic viscosity as temperature increased. This trend was followed by water-based mud with glass beads, water-based mud with polymer beads, and water-based mud until $100{ }^{\circ} \mathrm{C}$. These results showed that the presence of solids in drilling mud increases the viscosity. Polymer beads recorded lower plastic viscosity compared to glass beads. The absence of high-temperature additive in drilling mud was of main concern where the

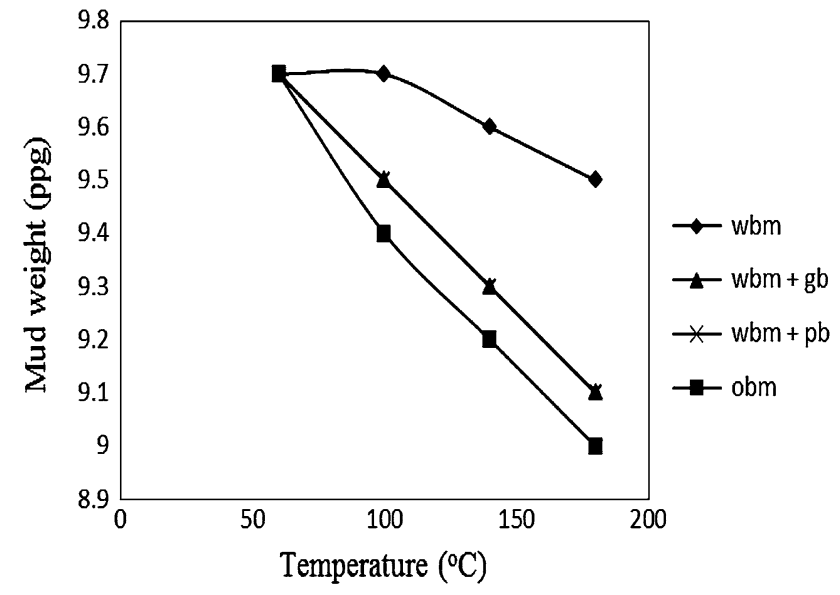

Fig. 6 Mud weight of drilling mud at elevated temperatures

drilling mud could not sustain its rheological properties. Despite the changes in plastic viscosity values, it still shows a comparable performance with Scomi Oiltools's recommended value of $20 \mathrm{cp}$. This happened after mud was exposed to elevated temperatures for $16 \mathrm{~h}$ in an aging cell. Except oil-based mud, the plastic viscosity of other mud samples was found to deteriorate after $100{ }^{\circ} \mathrm{C}$.

\section{Yield point}

Figure 8 shows the results of those four types of drilling mud after being exposed to elevated temperatures. The 


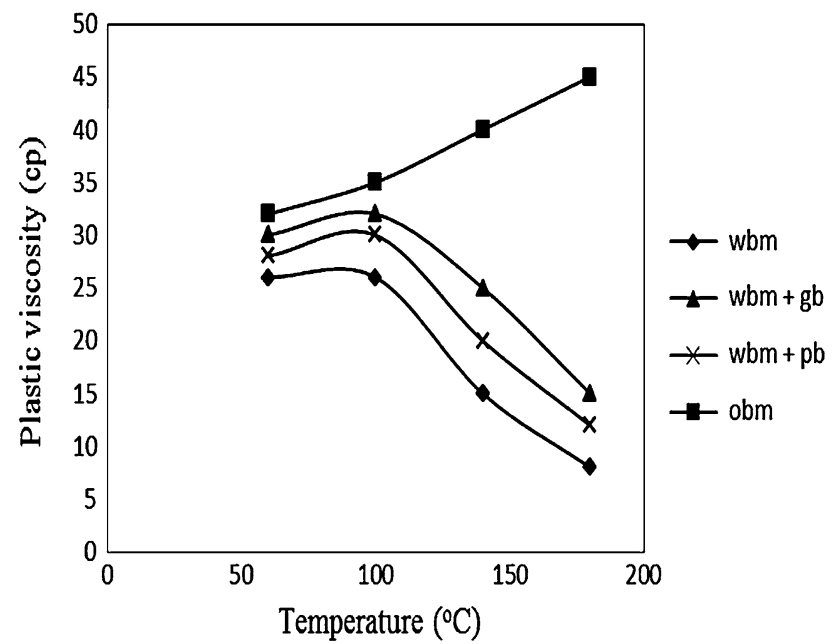

Fig. 7 Plastic viscosity of drilling mud at elevated temperature

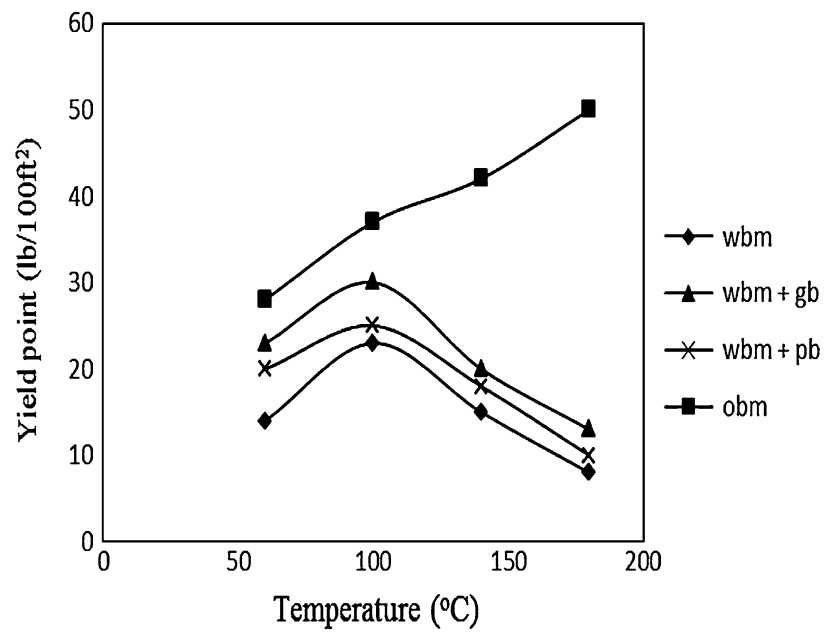

Fig. 8 Yield point of drilling mud at elevated temperature

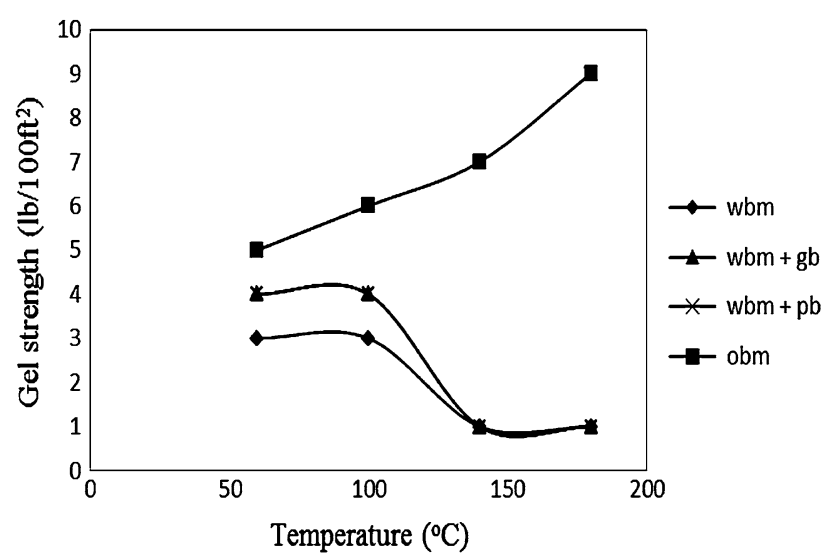

Fig. $910 \mathrm{~min}$ gel strength of drilling muds at elevated temperature oil-based mud experienced increase linearly in yield point as the temperature increased up to $180{ }^{\circ} \mathrm{C}$. But, waterbased mud plus glass beads, water-based mud plus polymer beads, and basic water-based mud increased in yield point up to $100{ }^{\circ} \mathrm{C}$ only and experienced decrease as temperature increased from $100{ }^{\circ} \mathrm{C}$ until $180{ }^{\circ} \mathrm{C}$. This is due to the effect of beads present in the mud. However, water-based mud with glass beads gave higher yield point compared to polymer beads. After $100{ }^{\circ} \mathrm{C}$, yield strength for waterbased mud and water-based mud with both solid lubricants decreased. The absence of high-temperature additive in drilling mud once again affected the mud rheological properties. The rheological properties were found to experience changes significantly above $100{ }^{\circ} \mathrm{C}$.

\section{Gel strength}

Figures 9 and 10 show the gel strength of the mud after being exposed to elevated temperatures. Oil-based mud revealed an increasing trend. This trend, however, was not followed by other drilling mud samples. All the drilling mud showed significant changes after $100{ }^{\circ} \mathrm{C}$. Again, it was found that the gel strength of drilling mud with polymer beads and glass beads was similar. This rapid reduction in gel strength, however, failed to match the result achieved by Lummus and Azar (1986), which stated the recommended initial gel strength of $2-8 \mathrm{lb} / 100 \mathrm{ft}^{2}$ for both $10 \mathrm{~s}$ and $10 \mathrm{~min}$. It shows that after $100{ }^{\circ} \mathrm{C}$, mud rheological properties were completely altered due to absence of high-temperature drilling mud additives.

\section{Fluid loss}

Figure 11 shows the fluid loss of the different types of mud under normal room condition. Water-based mud was found

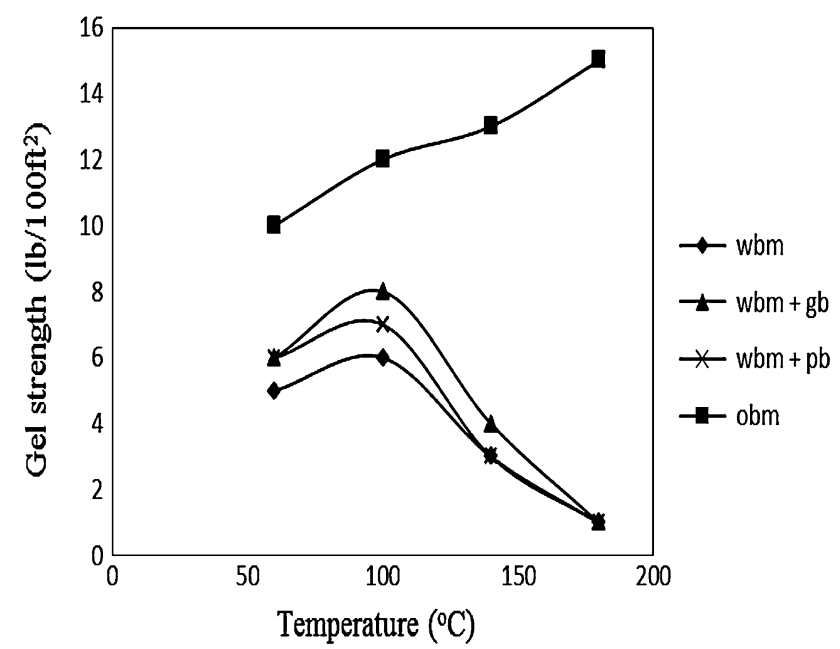

Fig. $1010 \mathrm{~s}$ gel strength of drilling mud at elevated temperature 


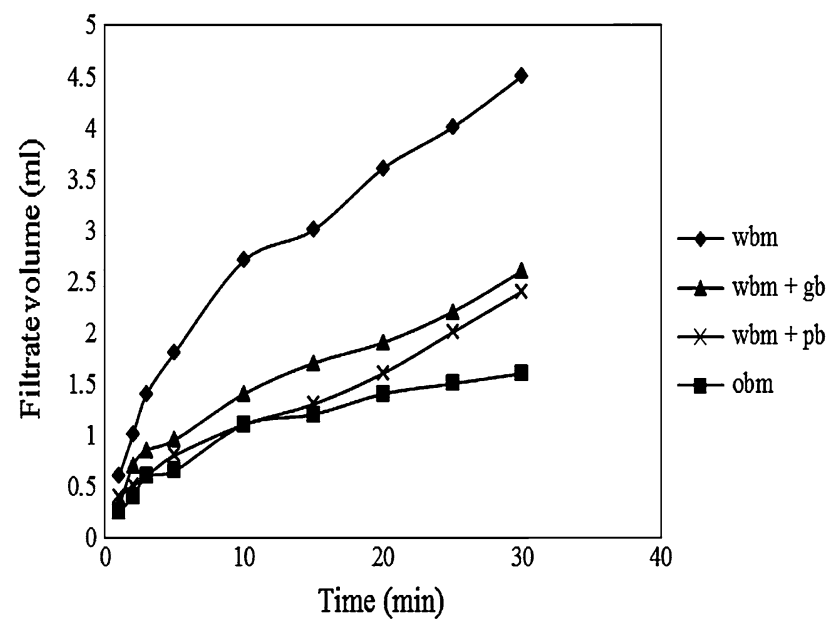

Fig. 11 Filtrate volume of drilling mud at normal room condition

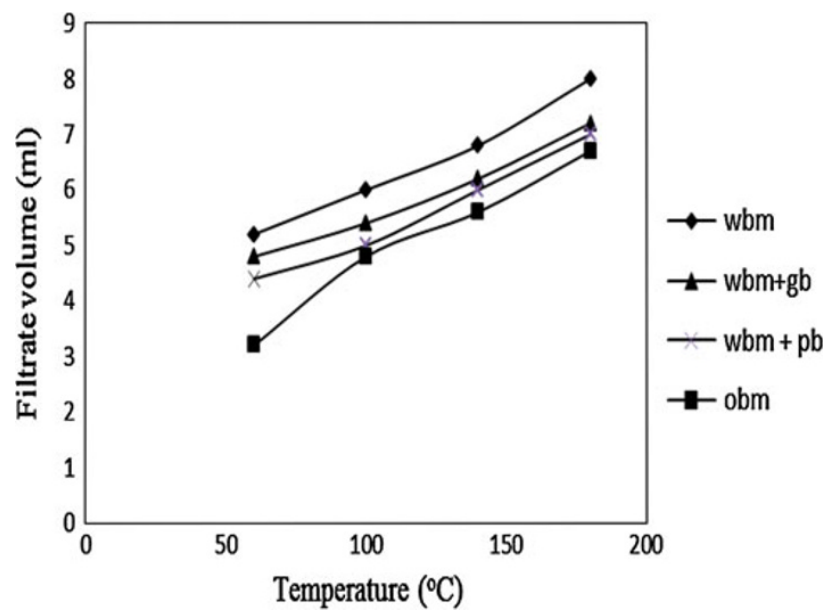

Fig. 12 Filtrate volume of drilling mud at elevated temperature

to produce the highest filtrate volume (i.e., $4.5 \mathrm{ml}$ ) as compared to others. Water-based mud with glass beads came next and followed by water-based mud with polymer beads and oil-based mud. They recorded 2.6, 2.4, and $1.6 \mathrm{ml}$ of filtrate loss, respectively. It showed that the presence of beads in drilling mud has significantly reduced filtrate loss. The volume of filtrate loss for all those drilling muds was found to be in a good agreement with field standard, which stated that the volume of filtrate loss should be less than $5 \mathrm{ml}$ (Bloemendal 1978).

The filtrate loss should be low enough to prevent excessive mud cake thickness and to reduce the chances of differential pressure sticking. Based on this statement, it was found that polymer beads produced lower filtrate volume compared to glass beads and water-based mud. According to Nazir and Ismail (2010), the presence of solid lubricants in the drilling mud seals the mud cake's pores, thus reduces the volume of filtrate loss. Based on the

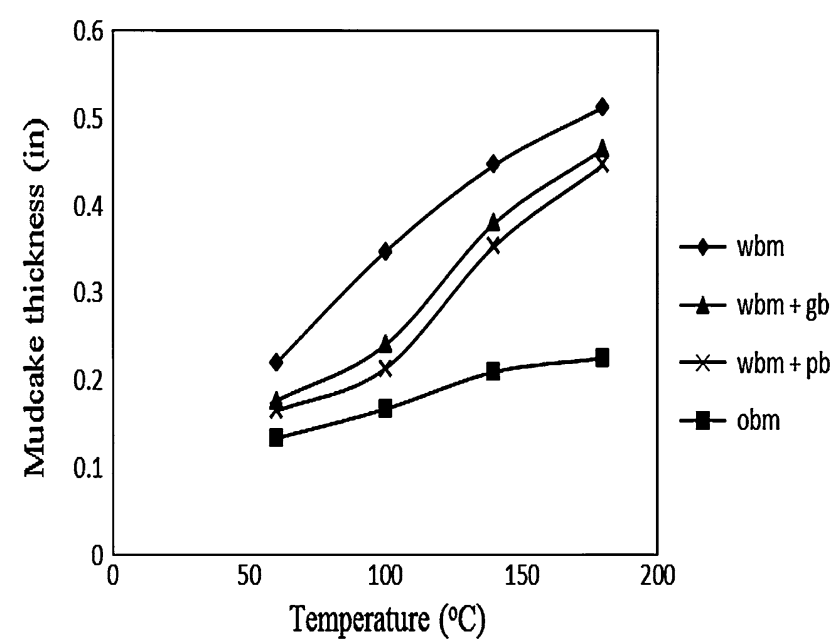

Fig. 13 Mud cake thickness of drilling mud at elevated temperature

experimental results, it showed that polymer beads are more effective in sealing the pores of mud cake than glass beads. Figure 12 shows the volume of filtrate loss for different types of mud that had been exposed to elevated temperatures. Water-based mud showed the highest volume of filtrate loss as temperature increased. It was followed by water-based mud with glass beads, water-based mud with polymer beads, and finally oil-based mud. It is important to keep the volume of filtrate as low as possible to create a thin and tough mud cake on a wellbore's porous surface. At high temperatures, polymer beads once again produced lower filtrate loss as compared to glass beads. This shows the ability of polymer beads to fill the pores in the mud cake, and thus prevents excessive amount of filtrate loss. Polymer beads characteristic which is not as brittle as glass beads contributes to this phenomenon where it will be more easily packed together than glass beads.

\section{Mud cake thickness}

Figure 13 shows the mud cake thickness of four different types of drilling mud at elevated temperatures. Waterbased mud produced thicker mud cakes as temperature increased. This trend was followed by water-based mud with glass beads, water-based mud with polymer beads, and oil-based mud. A similar trend was achieved at room temperature where water-based mud produced the thickest mud cake while oil-based mud gave the thinnest mud cake. Meanwhile, polymer beads were found to give a comparable performance at room and elevated temperature conditions, i.e., produced a thin mud cake compared to glass beads. Properties of polymer beads which were less brittle than glass beads allowed it to pack together, thus would reduce the thickness of its layer compared to glass beads. 


\section{Conclusions}

Based on the research works accomplished on polymer beads in water-based mud as a lubricating agent, several conclusions could be framed out accordingly:

1. Polymer beads constructed were compatible for hightemperature condition since it could sustain until $450{ }^{\circ} \mathrm{C}$. The chemical bonding of this polymer beads comprised benzene ring which makes it more resilient at high temperature.

2. These experimental results showed that polymer beads could be used as a lubricating agent in water-based mud at high-temperature wells. It gave a $27.5 \%$ of $\mathrm{CoF}$ reduction. This result was found to be comparable to the performance shown by commercial solid lubricant which gave $26.5 \%$ of $\mathrm{CoF}$ reduction. It was found to effectively reduce the $\mathrm{CoF}$ up to $100{ }^{\circ} \mathrm{C}$.

3. The use of polymer beads did change the rheological properties of water-based mud. Those properties, however, were found to be within the recommended field range or values.

Open Access This article is distributed under the terms of the Creative Commons Attribution License which permits any use, distribution, and reproduction in any medium, provided the original author(s) and the source are credited.

\section{References}

American Petroleum Institute (2009) Recommended Practice for Field Testing Water-based Drilling Fluid. (API-RP-13B-1), 4th edn. American Petroleum Institute, Dallas

Aston MS, Hearn PJ, and McGhee G (1998) Techniques for solving torque and drag problems in today's drilling environment. In: SPE 48939 presented at 1998 SPE Annual Technical Conference and Exhibition, New Orleans, Louisiana, 27-30 September

Bloemendal JW (1978) Recent development in drilling fluid technology. In: SPE 7102 presented at Offshore South East Asia Conference, 21-24 February

Cameroon C (2001) Drilling fluid design and management for extended reach drilling. In: IADC/SPE 72290 presented at
IADC/SPE middle east drilling technology, Bahrain, 22-24 October

Isnin MK, Bakar AA (2007) Optimized conditions for grafting reaction of poly (methyl methacrylate) onto oil palm empty bunch fiber (part II). Universiti Teknologi Malaysia, Malaysia

Kumar S, Affes S (2006) Successful application of exploration lessons learnt to deliver stretch HT/HP well delivery objectives (Krishna Godavari Basin, India).In: SPE/IADC 103997 presented at 2006 SPE/IADC Indian drilling technology conference and exhibition, Mumbai, India, 16-18 October 200

Lummus James L, Azar JJ (1986) Drilling Fluids Optimization a Practical Field Approach. Pennwell Publishing Company, Oklahoma

Murrey MD, Cipolla CL, Nor MN, Hussain HM (2003) Fracture design, execution and evaluation in retrograde condensate reservoirs: case history of the Angsi Field, offshore Malaysia.In: SPE 84395 presented at SPE annual technical conference and exhibition, Denver, Colorado, USA 5-8 October

Nazir F, Ismail I (2010) The performance of polymer and glass bead in water-based mud as a lubricating agent. Universiti Teknologi Malaysia

Nik Mat NS, Bakar AA (2007) Optimized conditions for grafting reaction of poly (methyl methacrylate) onto oil palm empty bunch fiber (part I). Universiti Teknologi Malaysia, Malaysia

Payne ML, Wilton BS, and Ramos GG (1995) Recent advances and emerging technologies for extended reach drilling. In: SPE 29920 presented at international meeting on petroleum engineering, Beijing, PR China, 14-17 November

Schamp JH, Estes BL (2006) Torque reduction techniques in ERD Wells. In: IADC/SPE 98969 presented at IADC/SPE drilling conference held in Miami, Florida, USA 21-23 February

Selamat S, Teletzke GF, Patel PD, Darman N (2008) The New Frontier in Malay Basin development. In: IPTC 12805 presented at the international petroleum technology conference, Kuala Lumpur, Malaysia 3-5 December

Skalle P, Backe KR, Lyomov SK, Kilaas L, Dyrli AD, and Sveen, J (1999) In: Microbeads as lubricants in drilling muds using a modified lubricity tester.In: SPE 56562 presented at 1999 SPE annual technical conference and exhibition, Houston, Texas, 3-6 October

Temco Inc (2006) LEM (Lubricity Evaluation Monitor)-4,100 Operations Manual. Temco, Houston

K\&M Technology Group (2003) Design and implementation for extended reach and complex wells. 3rd ed. attachment E: directional and extended reach drilling, USA

Rubiandini R (2008) Extended reach drilling (ERD) design in deepwater application. In: IADC/SPE 115286 presented at IADC/SPE Asia Pacific drilling technology conference and exhibition, Jakarta, Indonesia, 25-27 August 